\title{
Assessment of the Investment Appeal of Hydropower Construction Based on the Analytic Hierarchy Process
}

\author{
Olga Nikonova ${ }^{1}$, Olga Skvortsova ${ }^{1}$, Timofey Ivanov², Vitaly Terleev ${ }^{1}$, \\ Aleksandr Nikonorov $^{1, *}$, Issa Togo ${ }^{1}$, Yulia Volkova ${ }^{1}$ and Sergey Pavlov ${ }^{1}$ \\ ${ }^{1}$ Peter the Great St.Petersburg Polytechnic University, Polytechnicheskaya, 29, St. Petersburg, \\ 195251, Russia \\ 2“'B.E. Vedeneev VNIIG” JSC, Gjatskaya, 21, Saint Petersburg, 195220, Russia
}

\begin{abstract}
The purpose of the paper is description of the method of estimating the investment appeal rate of hydropower construction in the federal subjects. The method is based on Analytic Hierarchy Process (AHP). According to the method every federal subject is estimated by the decision-maker. The authors collected data for this study from Russian Federal State Statistics Service, the Federal Subjects Development Programs and the Power Industry Development Programs of the federal subjects (23 indicators). The federal subjects were estimated according to these indicators. As a result of this project every estimated federal subject has status: attractive, relatively attractive and non-attractive for hydropower development. The results can be applied to calculate the economic hydropower potential. The method was tested for detecting the attractive federal subjects of the Volga Federal District, North Caucasian Federal District, Northwestern Federal District, Siberian Federal District for hydropower development.
\end{abstract}

\section{Introduction}

Since the 1970th many countries have been working to establish renewable energy facilities operating on traditional and non-traditional energy sources. Hydropower is currently one of the major non-polluting and renewable resources. The world has accumulated a vast experience in design, construction and operation of hydropower plants (HPP) of various capacities [1].

Large-scale research studies of Russian river's hydropower potential are currently held in Russia to determine the location of feasible sites for the hydropower plants construction [25]. In many countries, such as Slovakia, France, Italy, Norway, USA, Canada, Turkey, Malaysia and South Africa the same studies have been fulfilled in the past few years [6-9].

*Corresponding author: coolhabit@yandex.ru 
A significant part of the research studies is focused on solving hydropower related tasks with the use of GIS technology [10-23].However, recent large-scale research of hydropower potential of Russian rivers by S.V. Grigoriev, A.N. Voznesenskiy and B.N. Feldman were fulfilled in 1940-1980th [24-25]. Construction of HPP served as an impetus for economic development of entire regions for many years. Nevertheless, hydropower potential of Russia is investigated and used insufficiently. Percentage of used hydroenergy resources of Russia is about $23 \%$. At the same time, the percentage is much higher for the most of developed countries: $95 \%$ for Germany, 95\% for France, 95\% for Italy, $84 \%$ for Japan, $90 \%$ for the United Kingdom, $82 \%$ for US, $65 \%$ for Canada.

Most of Russia's hydropower potential is concentrated in Eastern Siberia and the Far East: basins of Yenisei, Lena and Amur rivers. It is possible to build more than 10 powerful HPP with a total capacity of more than $30 \mathrm{GW}$ and the generation of $100 \mathrm{blnkW} \cdot \mathrm{h}$. The production may be carried out to the Urals and further to the European part of the country along the lines of DC and AC EHV (extra high voltage). HPP construction in the Far East deals with the projects of extracting and processing of mineral resources. Usage of Russia's European part hydro resources is only feasible on the medium and small rivers. Estimation of gross and technical hydropower potential of the rivers may be fulfilled with a use of GIS technologies $[5,23]$.

The task of river scheme analysis at a prefeasibility stage is obviously a multi-criteria one [27]. Solving the problem of determining the economic hydro potential of a river deals with analysis of future consumers, cost of infrastructure, furthermore even the political restrictions and socio-economic situation in the region should be taken into account.

\section{Materials and methods}

Authors have developed a technique of estimating the investment appeal rate of hydropower development at the level of Russian federal subjects. The technique is based on economical, technical, socio-demographical data. Sophisticated software allowing the graphical-analytical method to evaluate the investment appeal rate of federal subjects was created for this purpose [28, 29].

Following requirements for the federal subjects suitable for hydropower projects were stated:

- current or future power and electrical shortage;

- positive trends of socio-demographic indicators of the federal subject;

- presence of potential consumers of electricity in the federal subject;

- favourable complex indicators of the federal subject;

- positive dynamics in the growth of economic indicators in the federal subject.

Using the mentioned requirements, the authors have formulated 23 indicators that characterize the current state of the economy, power market and socio-demographic situation in the federal subject, as well as their predicted values (Fig. 1). Comparison of the data was performed along the lines of linear regression and the median values for the period 2007-2018. 


\begin{tabular}{|c|c|}
\hline \multicolumn{2}{|c|}{ G1 (power consumption and generation) } \\
\hline power consumption & 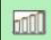 \\
\hline per capita power consumption & $M$ \\
\hline power system peak load & ह-⿴囗十) \\
\hline power plant' capacity & 맴] \\
\hline power plant' generation & 매묘] \\
\hline over-generation / energy shortfall & [재] \\
\hline electric power lines' development & [짐] \\
\hline fossil fuels availability & कात्रा \\
\hline
\end{tabular}

Fig. 1. Indicators that characterize the attractiveness of a region for hydropower development.

Analytic Hierarchy Process (AHP) by Thomas L. Saatywas used as a basis for this article. The method is intended to solve multicriterial problems with a finite set of possible vectors and allows comparison of options without their absolute rating scale [30].

The method suggests decomposition of the problem into simple component parts and further processing of the sequence of judgments by experts. The result may be expressed as a numerical relative degree of the element's interaction in the hierarchy. According to the method, an expert carries pairwise comparison of all criteria using the scale of the relative importance of the quantitative value expressing the degree of superiority of one criterion to another. This forms a matrix of pairwise comparisons.

The indicators taken into account were grouped (Fig. 1). Weighting factors were calculated for each group of indicators.

Each analyzed federal subject has been assessed on 23 indicators, separated into six groups, with the help of specially developed software. The researched area was chosen on an interactive map. Special forms were used to input the data. Then the analytical information that reflects the current state and dynamics of the federal subject was used in specially developed analytical tool to provide the scores for each federal subject.

Each indicator of the study area is given a certain numerical value, which reflects the dynamics of change in the federal subject (below average - "0", unchanged - "1", above average - "2").

Further, the total regional investment appeal rate coefficient $\left(\mathrm{K}_{\text {summ }}\right)$ for each analyzed federal subject was calculated the following way:

$$
K_{\text {summ }}=\sum_{i=1}^{n}\left(K_{\text {group }} * W_{i}\right)
$$

where $_{\text {summ }}$ is a sum of the values of criteria of group $\mathrm{i}$ :

$$
K_{\text {group }}=\sum_{j=1}^{m}\left(K_{j}\right)
$$

The weights $\left(\mathrm{W}_{\mathrm{i}}\right)$ and threshold values $\left(K_{\text {summ }}^{\text {NonP }}, K_{\text {summ }}^{N P}\right)$ have been defined using the analytic hierarchy process. 
Hierarchy tree consisting of two levels was compiled to provide the decomposition of the task to determine the federal subject with a high investment appeal rate (Fig. 2).

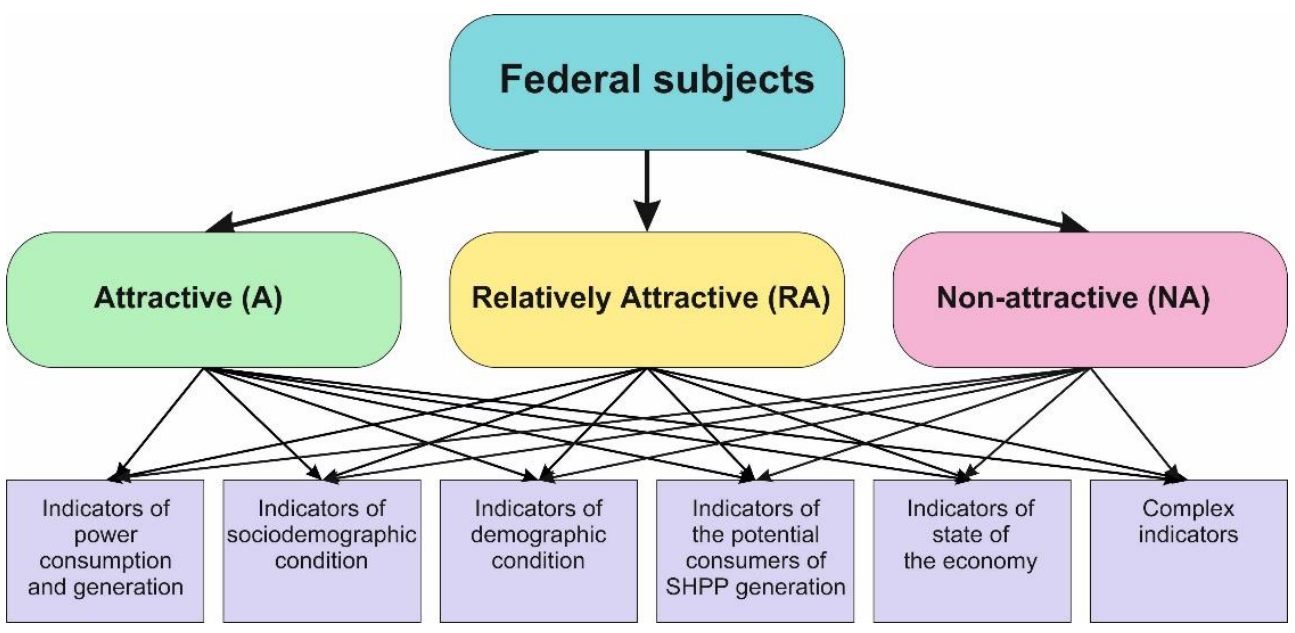

Fig. 2. The hierarchy tree.

The purposes of creating the hierarchy tree are:

- defining the percentages of attractive, relatively attractive and non-attractive federal subjects for hydropower construction;

- defining factors of importance for groups indicators G1-G6 according to expert's opinion.

Relatively attractive federal subject means that HPP construction is possible, but it requires a more detailed analysis, including an analysis of the possibility of additional government or regional subsidies. Knowing the described percentage, authors can determine the threshold values for the coefficient $\mathrm{K}_{\text {summ. }}$. The experts' task is to express their views on the importance of criteria G1-G6 in respect of one another.

When compiling the matrix of first level pairwise comparisons, experts are suggested to assess the percentage of non-attractive, relatively attractive and attractive federal subjects.

Then the expert was asked to make a paired comparison of the importance of groups of indicators G1-G6. Filling in the table of pairwise comparisons, the expert shows the importance of one group of factors comparing to the other group.

The expert expresses his opinion using the scale of relative importance, developed by Saaty and Kerns for Analytic Hierarchy Process (Table. 1).

Table 1. Scale of relative importance.

\begin{tabular}{|c|l|}
\hline $\begin{array}{c}\text { Degree relative } \\
\text { importance }\end{array}$ & \multicolumn{1}{c|}{ Annotations } \\
\hline 1 & Similar importance \\
\hline 3 & Moderate superiority of one over another \\
\hline 5 & Significant superiority \\
\hline 7 & Strong superiority \\
\hline 9 & Very strong superiority \\
\hline $2,4,6,8$ & $\begin{array}{l}\text { Intermediate degree between two neighboring inferences (are } \\
\text { applied in a compromise case) }\end{array}$ \\
\hline
\end{tabular}


Inverse values of the degrees given above
It means when comparing first and second indicator values it's calculating one of the above-stated degree (for example 3), then when comparing the second and first indicator values we will calculate an inverse value (i.e. 1/3)

Then experts expressed their opinion on how important the group G1-G6 indicators in determining the attractiveness of a federal subject. Using the answers three matrixes of second level pairwise comparisons were formed. Because of processing, the three sets of importance coefficients were calculated. Each set reflects the distribution of importance of groups of indicators G1-G6 for unviable, relatively attractive and attractive federal subjects. The described algorithm has been implemented using Mathcad software, taking into account the views of decision-makers. Matrixes of pairwise comparisons were formed (Fig. $3)$.

For a matrix of pairwise comparisons, eigenvalues of a given matrix were calculated, and then the compatibility index was checked not to exceed the value of 0.1 . A system of linear equations was made, and a solution for it was found in the form of a column of the normalized weight ratios. Figure 3 shows an example of calculation for a matrix of pairwise comparisons of attractive federal subject.

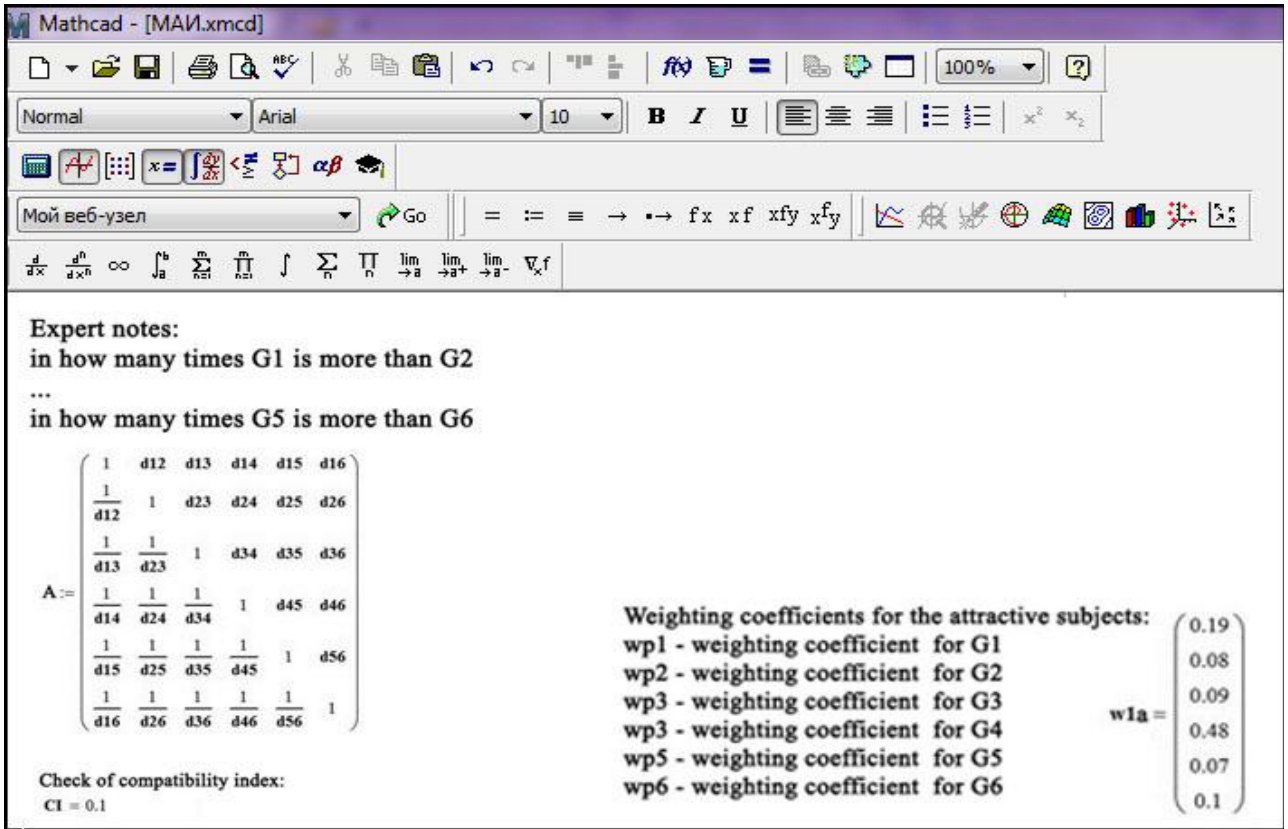

Fig. 3. Example of Expert assessment via Mathcad software.

An analysis of the attractiveness of the federal subject was carried out by comparing the total coefficients of attractive federal subject $\left(\mathrm{K}_{\text {summ }}\right)$ with thresholds.

The threshold value of $\left(\mathrm{K}_{\text {summ }}\right)$ was determined on the basis of its theoretically possible value and importance of the first level coefficients:

$$
K_{\text {summ }}^{\max }=\sum_{i=1}^{m}\left(2 * m_{i} * W_{i}\right)
$$

where 2 is a maximum possible value of indicators; 
$\mathrm{m}_{\mathrm{i}}$ - number of indicators in group $\mathrm{i}$;

$\mathrm{W}_{\mathrm{i}}$ - weighting coefficient of influence indicators group $\mathrm{i}$.

The threshold value $\left(K_{\text {summ }}^{N A}\right)$ in allocating non-attractive federal subjects:

$$
K_{\text {summ }}^{N A}=W^{N A} * K_{\text {summ }}^{\max },
$$

where $\mathrm{W}^{\mathrm{NA}}$ is weighting coefficient of the attractive federal subjects; $K_{\text {summ }}^{\max }$ is a theoretically possible value $\left(\mathrm{K}_{\text {summ }}\right)$

The threshold value $\left(K_{\text {summ }}^{R A}\right)$ in allocating attractive federal subjects:

$$
K_{\text {summ }}^{R A}=K_{\text {summ }}^{N A}+W^{R A} * K_{\text {summ }}^{\max },
$$

where $\mathrm{W}^{\mathrm{RA}}$ - weighting coefficient of the attractive federal subjects;

$K_{\text {summ }}^{\max }$ - theoretically possible value $\left(\mathrm{K}_{\text {summ }}\right)$.

\section{Results and discussions}

As a result of calculations it was defined: weighting coefficients of indicators' groups G1 G6; ratio of attractive, relatively attractive and non-attractive federal subjects; threshold values of the total regional investment appeal rate coefficient (Fig. 4).

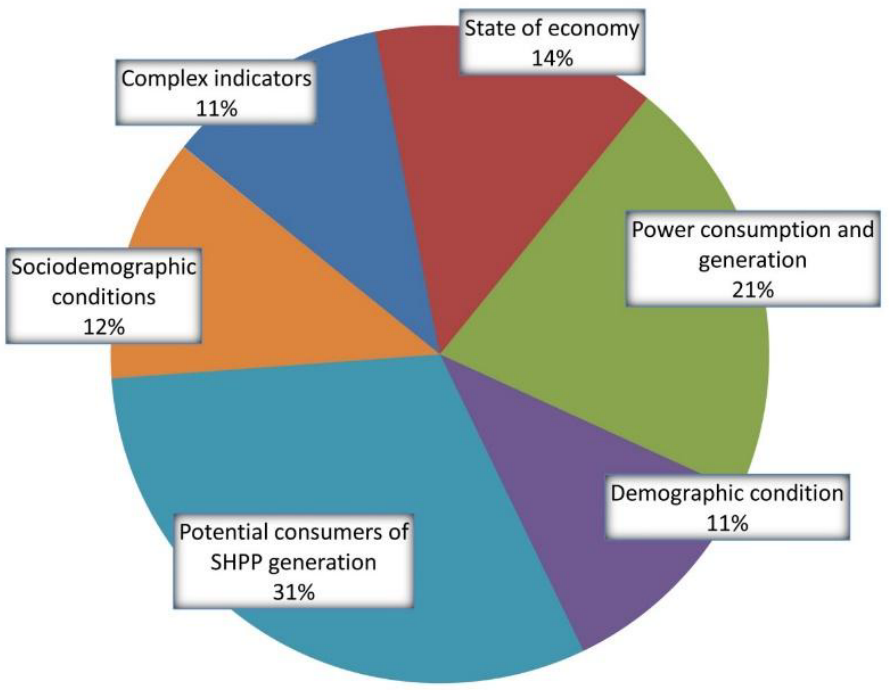

Fig. 4. Value of weighting coefficients of indicators' groups.

Thus, all researched federal subjects were classified as attractive, relatively attractive or non-attractive after comparing values of the federal subjects with thresholds. The map of regional investment appeal rate may be formed as a result of the allocation (Fig. 5). 


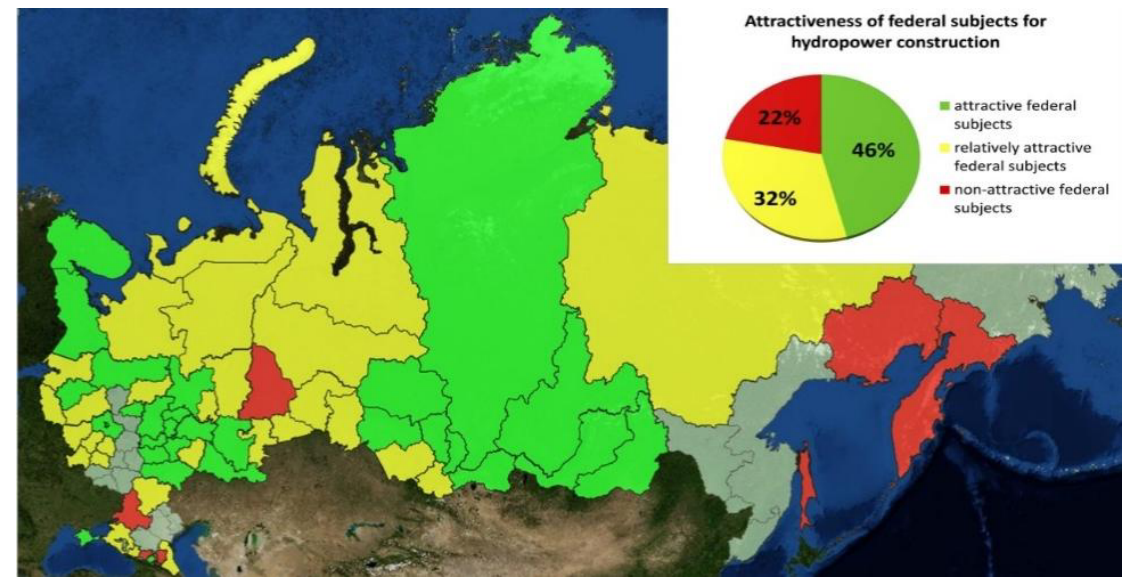

Fig. 5. Map of regional investment appeal rate for hydropower (green - attractive, yellow - relatively attractive, red - non- attractive, grey - no data).

In the subsequent calculations of economic hydropower potential only attractive and relatively attractive federal subjects were analyzed.

\section{Summary}

Suggested method of estimating the investment appeal rate of hydropower construction in the federal subjects is based on the Analytic Hierarchy Process. The method allows evaluating the current and forecasted investment appeal rate the federal subject. As a result of its application the coefficients of attractiveness are calculated for each analyzed federal subject, and also thresholds of indicated factor are determined in allocating federal subjects to non-attractive, relatively attractive and attractive [31]. Comparing the results of the above-mentioned technique with a traditional analysis of investment appeal rating showed a good correlation. [30]. The proposed method is especially effective at the early stages of the design (prefeasibility studies). A significant advantage of the approach is an ability to make a decision having some factors that can't be quantified. This feature is particularly important for environmental issues when due to a variety of indicators the assessment can be given in the form of a set of characteristics, graphs, and verbal description.

\section{References}

1. N.V. Badenko, N.S. Bakanovichus, O.K. Voronkov, T.S. Ivanov, A.A. Lomonosov, V.A. Oleshko, M.V. Petroshenko,MCE6, 62-72 (2013)

2. N.V. Arefiev, N.L. Badenko, T.S. Ivanov, S. Kotlyar, O.G. Nikonova, V.A. Oleshko, AMM725726, 285-292 (2015)

3. T.L. Saaty, The Hierarchon: A Dictionary of Hierarchies (Pittsburgh, Pennsylvania: RWS Publications, 1992)

4. N. Arefiev, V. Garmanov, V. Bogdanov, Yu. Ryabov, V. Terleev, V. Badenko, Procedia Eng. 117(1) 26-31 (2015)

5. N. Arefiev, V. Terleev, V. Badenko, Procedia Eng. 117 39-44 (2015)

6. O. Skvortsova, A. Dashkina, E. Petrovskaia, V. Terleev, A. Nikonorov, V. Badenko, Yu. Volkova, S. Pavlov, MATEC web conf. 53, Article no 01014 (2016) 
7. O. Degtyareva, G. Degtyarev, I. Togo, V. Terleev, A. Nikonorov, Y. Volkova, Procedia Eng. 165, 1619-1628 (2016)

8. A. Nikonorov, V. Badenko, V. Terleev, I. Togo, Y. Volkova, O. Skvortsova, O. Nikonova, S. Pavlov, W. Mirschel, Procedia Eng. 165, 1731-1740 (2016)

9. N.N. Semenova, V.V. Terleev, G.I. Suhoruchenko, E.E. Orlova, N.E. Orlova, Vestnik St. Petersburg University: Mathematics 49, 138-146 (2016)

10. A. Makarov，A. Mihailova， N. Arefiev，S. Pavlov，T. Chashchina，V. Terleev，V. Badenko, Procedia Eng. 117, 225-231 (2015)

11. V.V. Terleev, A.G. Topaj, W. Mirschel, Russ meteorol hydro+ 40, 278-285 (2015)

12. V. Terleev, E. Petrovskaia, N. Sokolova, A. Dashkina, I. Guseva, V. Badenko, Yu. Volkova, O. Skvortsova, O. Nikonova, S. Pavlov, A. Nikonorov, V. Garmanov, W. Mirschel, MATEC web conf. 53, Article no 01013 (2016)

13. N. Arefiev, V. Badenko, A. Nikonorov, V. Terleev, Y. Volkova, Procedia Eng. 117, 20-25 (2015)

14. A. Nikonorov, S. Pavlov, V. Terleev, N. Arefiev, V. Badenko, Y. Volkova, Procedia Eng. 117, 258-263 (2015)

15. V. Terleev, A. Nikonorov, V. Badenko, I. Guseva, Y. Volkova, O. Skvortsova, S. Pavlov, W. Mirschel, Advances in Civil Engineering 2016, 8176728, 1-7 (2016)

16. V. Terleev, E. Petrovskaia, A. Nikonorov, V. Badenko, Y. Volkova, S. Pavlov, N. Semenova, K. Moiseev, A. Topaj, W. Mirschel, MATEC web conf. 73, Article number 03001 (2016)

17. R.A. Poluektov, V.V. Terleev, Russ meteorol hydro+ 11, 70-75 (2002)

18. R.A. Poluektov, I.V. Oparina, V.V. Terleev, Russ meteorol hydro+ 11, 61-67 (2003)

19. R.A. Poluektov, S.M. Fintushal, I.V. Oparina, D.V. Shatskikh, V.V. Terleev, E.T. Zakharova, Arch. Acker- Pfl. Boden. 48, 609-635 (2002)

20. R.A. Poluektov, V.V. Terleev, K.Ch. Kersebaum, J.-M. Hecker, W. Mirschel, M. Wegehenkel (Eds), Leibniz Centre of Agricultural Landscape Research (ZALF) in Müncheberg/Germany, 75$89,(2007)$

21. V. Badenko, V. Terleev, A. Topaj, AMM 635-637, 1688-1691 (2014)

22. S. Medvedev, A. Topaj, V. Badenko, V. Terleev, IFIP AICT, 448, 252-261 (2015)

23. V. Badenko, V. Terleev, N. Arefiev, J. Volkova, O. Nikonova. Proceedings of the AASRI International Conference on Industrial Electronics and Applications (IEA 2015). Book Series: AER-Advances in Engineering Research. 2, 452-455 (2015)

24. R.A. Poluektov, V.V. Terleev, Russ meteorol hydro+ 12, 73-77 (2005)

25. V.V. Terleev, W. Mirschel, U. Schindler, K.-O. Wenkel, INT AGROPHYS. 24, 381-387 (2010)

26. V. Terleev, A. Nikonorov, I. Togo, Y. Volkova, V. Garmanov, D. Shishov, V. Pavlova, N. Semenova, W. Mirschel, Procedia Eng. 165, 1776-1783 (2016)

27. A. Nikonorov, V. Terleev, S. Pavlov, I. Togo, Y. Volkova, T. Makarova, V. Garmanov, D. Shishov, W. Mirschel, Procedia Eng. 165, 1741-1747 (2016)

28. V. Chechevichkin, N. Vatin, AMM 641-642, 409-415 (2014)

29. N. Arefiev. M. Mikhalev, D. Zotov, K. Zotov, N. Vatin, O. Nikonova, O. Skvortsova, S. Pavlov, T. Chashina, T. Kuchurina, V. Terleev, V. Badenko, Y. Volkova, V. Salikov, K. Strelets, M. Petrochenko, A. Rechinsky, Procedia Eng. 117, 32-38 (2015)

30. V. Badenko, N. Badenko, A. Nikonorov, D. Molodtsov, V. Terleev, J. Lednova, V. Maslikov, MATEC web conf. 73, Article number 03003 (2016)

31. N.V. Arefiev, N.V. Badenko, T.S. Ivanov, O.G. Nikonova and V.A. Oleshko, Proceedings of the International Scientific and Practical Conference. 2, 41-50 (2015) 